\title{
Hydrometeorological monitoring in the Nizhny Novgorod NPP siting area
}

\author{
Fedor Bryukhan ${ }^{1 *}$, Aleksey Vinogradov ${ }^{2}$, and Ivan Vinogradov ${ }^{3}$ \\ ${ }^{1}$ Moscow State University of Civil Engineering, Yaroslavskoe shosse, 26, Moscow, 129337, Russia \\ ${ }^{2}$ Saint Petersburg State Forest Technical University, Institutskiy per., 5, Saint-Petersburg, 194021, \\ Russia \\ ${ }^{3}$ Scientific \& Industrial Association Gidrotekhproekt, Oktyabr'skaya str. 55A, Valday City, Novgorod \\ Region, 175400, Russia
}

\begin{abstract}
Ensuring the technological and environmental safety of nuclear power plants (NPP) involves the collection and analysis of data on the state of the natural environment near nuclear power plants, including the atmosphere and surface waters. To obtain and organize such data, as well as for their subsequent processing and engineering calculations, appropriate monitoring observations are provided. The latter begin to be carried out long before the start of NPP construction and continue at all stages of the NPP life cycle, including the periods of construction, operation and decommissioning of the plant. The purpose of this research is to summarize the results of hydrometeorological monitoring at the Nizhny Novgorod NPP site and its vicinity, which was launched by the Scientific \& Industrial Association Gidrotekhproekt in 2011. The description of stationary observation points and examples of calculation of regime hydrological and meteorological characteristics are given. It is noted that the accumulation of observation data series over a long period of time, which make it possible to identify potential climate changes in the study area, is of great importance.
\end{abstract}

\section{Introduction}

The regime of the boundary layer of the atmosphere (approximately 1-kilometer low), as well as the hydrological regime of water bodies, in a great extent determines the technological, radiation and environmental safety of nuclear power plants (NPP) in the areas adjacent to the NPPs at various stages of their life cycle [1-4]. Due to this fact, a systematic collection, analysis and statistical processing of data on the parameters of the air and water environments in the NPP siting areas is carried out to arrange safety measures for the NPP. One of the means of obtaining such data is the relevant monitoring observations [4-6]. Such routine observations are stipulated by the regulatory documents in force in Russia, as well as by the recommendations of the International Atomic Energy Agency (IAEA) [3, 5-8]. Hydrometeorological monitoring usually begins at the design stage of the NPP and continues during its construction and operation. It should be emphasized that

* Corresponding author: pniiis-gip@mail.ru 
hydrometeorological monitoring is a component of the automated radiation monitoring system (ARMS), which controls the territory surrounding the NPP.

The main objectives of hydrometeorological monitoring include the following:

- clarification of the characteristics of the climatic regime of the atmospheric boundary layer and the water regime of the area surrounding the NPP;

- obtaining a set of input data to substantiate the technological, radiation and environmental safety of nuclear power plants, including threats from the effects of hazardous hydrometeorological phenomena and processes;

- forecasting of technogenic changes in landscape components as a result of the construction and operation of the NPP [7].

The primary basis for information on the state of water and air are the results of engineering and hydrometeorological surveys carried out earlier by the Scientific \& Industrial Association Gidrotekhproekt (SIA Gidrotekhproekt) in 2011-2012.

At present, the construction of Nizhny Novgorod NPP has been suspended for organizational reasons. Nevertheless, if the construction continues, the results of the monitoring observations already performed will be very essential for the implementation of the above tasks.

The purpose of this research is to summarize the results of hydrometeorological monitoring observations at the Nizhny Novgorod NPP site and its vicinities, the said observations were carried out by the SIA Gidrotekhproekt in the period from August 2011 to September 2018.

\section{Monitoring system}

The location of the Nizhny Novgorod NPP was planned in Navashinsky district of the Nizhny Novgorod region near the village of Monakovo, a few kilometers from it. The Oka River flows not far from the NPP site (at a distance of 4-6 km to the north and west of its center). The area adjacent to the NPP site is a slightly rugged plain with a relief characteristic of the central section of the European part of the Russian Federation.

\subsection{Monitoring network}

The hydrometeorological network of the surveyed area is localized in the Volga River basin and is located in the northern part of the Volga Upland [4], such as:

- 4 stationary hydrological posts controlled by the SIA Gidrotekhproekt;

- 4 stationary water level gauge posts belonging to the national hydrometeorolocal service (Rosgidromet);

- the Monakovo meteorological station of the SIA Gidrotekhproekt;

- 3 meteorological stations belonging to the Rosgidromet.

\subsection{Hydrological observations}

At the hydrological posts set up by the SIA Gidrotekhproekt, observations were made of the water level, its discharge and temperature, ice regime, turbidity, as well as hydrochemical and bacteriological characteristics. At one of the water level gauge posts near the village of Chud' on the 800-meter stretch of the Oka River, the speed and direction of the water current were investigated. In addition to the above, observations were also made of the deformations of the river's right bank in the area of planned construction of the coastal pump station. The indicated observations make it possible to determine the rate of deformation of the river channel and banks in a given portion of the river. 
The observation posts of the SIA Gidrotekhproekt were equipped with automated water level recorders. They periodically measured water levels and flow rates, as well as made water sampling. Then, in the laboratories water samples were examined for turbidity and their hydrochemical and bacteriological characteristics. Additionally, photographs were taken of the phases of the water regime.

The data obtained as a result of hydrological monitoring observations significantly expand and supplement the information on the water regime of the study area. New data on extreme hydrological characteristics are of special importance.

\subsection{Meteorological observations}

The meteorological station of the SIA Gidrotekhproekt was installed in the village of Monakovo at a distance about $2 \mathrm{~km}$ from the NPP site. The location of the meteorological site was chosen in compliance with the requirements of the national hydrometeorological service. When studying the climate of the NPP site vicinity area, data from the meteorological stations Murom, Pavlovo and Viksa were also used.

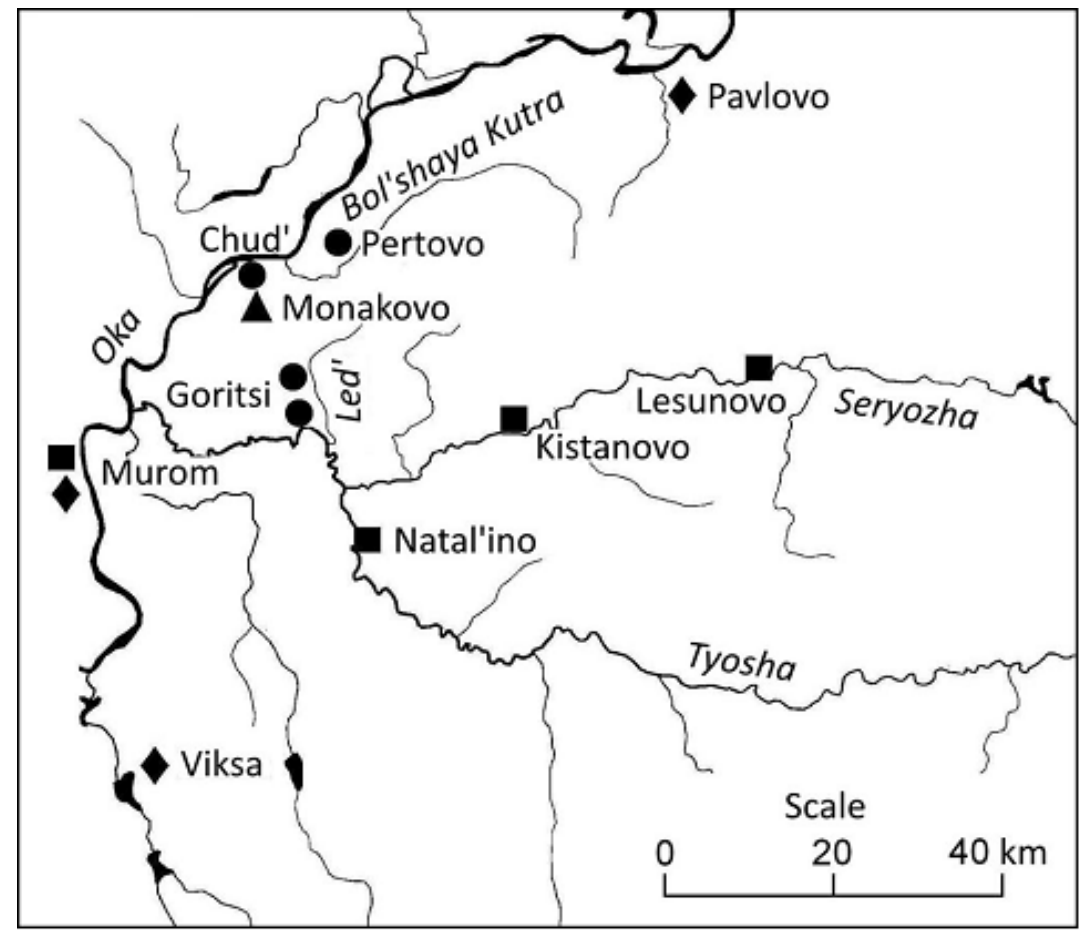

Fig. 1. Points of monitoring observations:

- - hydrological posts of the SIA Gidrotekhproekt;

- - hydrological posts of the Rosgidromet;

- - meteorological station of the SIA Gidrotekhproekt;

- meteorological stations of the Rosgidromet

Meteorological data in the village of Monakovo were measured every 3 hours 8 times a day using standard instruments. The observation results showed insignificant differences between the operating data at the NPP site from the corresponding data at the nearest meteorological station Murom. These differences turned out to be within the limits of the 
allowable statistical errors. Therefore, the Murom meteorological station with a long series of observations can be considered representative of the NPP site. This circumstance provides a fairly reliable assessment of extreme meteorological characteristics.

\section{Results and discussion}

All registered results of monitoring observations are entered into databases where they are accumulated. Further, the data are checked, statistically processed, and averaged characteristics are calculated for individual months, seasons and years. The results of statistical processing and analysis of data are issued in the form of current annual reports that are used by various interested organizations.

As an example, Figure 2 shows graphs of the annual changes of water levels and water discharges at the hydrological post of Tyosha river near Goritsy village for 2015-2017. The level and discharge hydrographs shown in Figure 2 are typical of rivers in the middle zone of the European part of Russia.
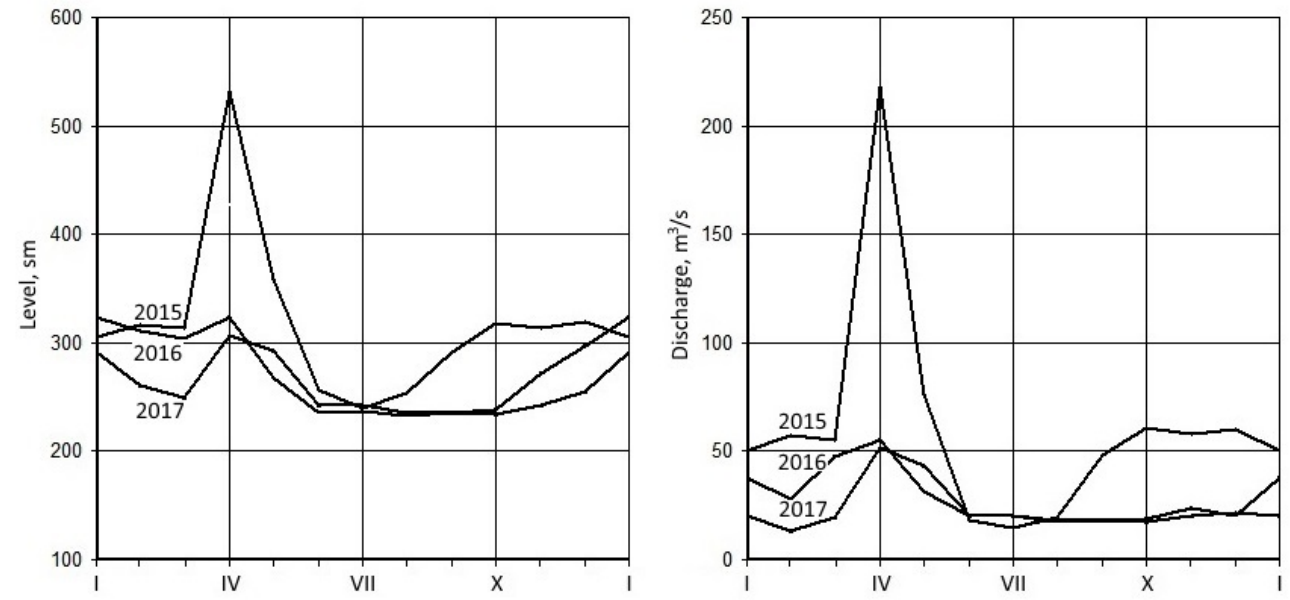

Fig. 2. Annual changes of water levels and water discharges at the hydrological post of Tyosha river near Goritsy village in different years

Figure 3 shows graphs of the annual changes of air temperatures and wind speeds at the Monakovo meteorological station for 2015-2017. According to the graphs, the air temperature is characterized by relative stability, while the wind speed demonstrates significant variability, which is particularly apparent during colder months.

An analysis of the monitoring observation results showed a close correspondence of the characteristics of the water regime and the surface atmospheric layers in the study area with the results of earlier engineering surveys.

The results of hydrometeorological monitoring have already been applied in preliminary design work to justify the engineering protection of Nizhny Novgorod NPP from the impact of hazardous and extremely hazardous hydrological and meteorological factors.

It should be noted that the above-described hydrometeorological monitoring will prove to be an important additive to the ARMS in the siting area. It should also be emphasized that the experience of organizing and conducting hydrometeorological monitoring will also be useful for the siting areas of other NPPs. If the construction of the nuclear power plant continues, the SIA Gidrotekhproekt plans to equip the monitoring system with equipment for remote measurement of wind and temperature in the atmosphere [9]. Such 
measurements, as shown by the experience of the SIA Gidrotekhproekt at the Belarussian NPP site [10], make it possible to successfully study the atmospheric dispersion.
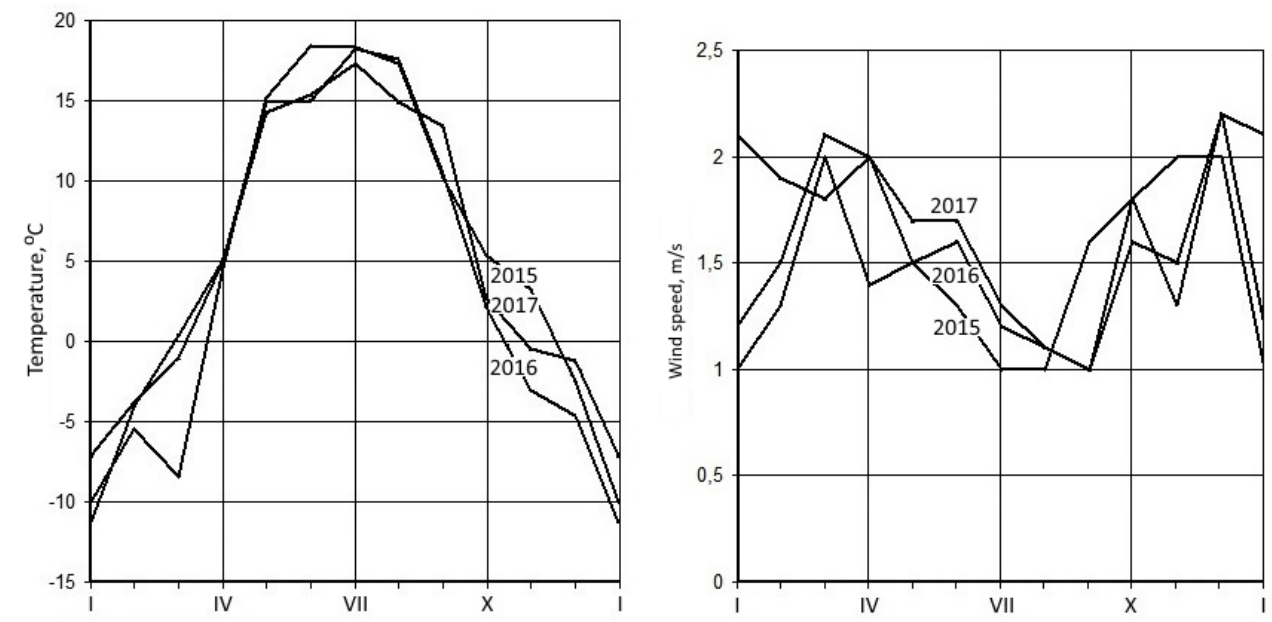

Fig. 3. Annual changes of air temperatures and wind speeds at the Monakovo meteorological station for 2015-2017

\section{Conclusions}

- The hydrometeorological monitoring system in the siting area of the Nizhny Novgorod NPP is an important component of the ARMS designed to control the territories surrounding the NPP.

- The combination of data from the national observation network Rosgidromet and data from hydrometeorological monitoring by the SIA Gidrotekhproekt makes it possible to achieve a significant clarification of information about the climatic and water regimes in the studied area.

- A description of stationary posts of hydrometeorological observations is given and calculations of routine hydrological and meteorological characteristics for the period August 2011 - September 2018 have been performed.

- The experience gained in organizing and conducting monitoring of water and air environments will be useful for the siting areas of other NPPs.

The authors thanks the specialists of the SIA Gidrotekhproekt for their help and useful discussions.

\section{References}

1. F.F. Bryukhan, Nuc. Technol. Radiat., 35, 1 (2020)

2. L. Devell, B. Lauritzen (Eds.), Radiological emergency monitoring systems in the Nordic and Baltic Sea countries (Danka Services International, Roskilde, Denmark, 2001)

3. Radiation protection aspects of design for nuclear power plants: draft safety guide. IAEA safety standards series, no. NS-G-1.13 (IAEA Publishing House, Vienna, 2004)

4. F. Bryukhan, A. Vinogradov, I. Vinogradov, M. Vinogradova, Hydrological and meteorological monitoring in the Nizhny Novgorod NPP siting region, in Proceedings 
of the 18-th International Multidisciplinary Scientific GeoConference, SGEM-2018, 30 June - 9 July 2018, Albena, Bulgaria (2018)

5. Environmental and source monitoring for purposes of radiation protection: safety guide. IAEA safety standards, no. RS-G-1.8 (IAEA Publishing House, Vienna, 2005)

6. Engineering surveys for the location, design and construction of nuclear power plants. Russian standard SP 151.13330.2012, Part 2 (Moscow, Gosstroy of Russia, 2012)

7. Meteorological and hydrological hazards in site evaluation for nuclear installations: specific safety guide. IAEA safety standards, no. SSG-18 (IAEA Publishing House, Vienna, 2011)

8. Dispersion of Radioactive Material in Air and Water and Consideration of Population Distribution in Site Evaluation for Nuclear Power Plants: safety guide. IAEA safety standards, no. NS-G-3.2 (IAEA Publishing House, Vienna, 2002)

9. The METEK Radio Acoustic Sounding System (METEK, Elmshorn, Germany, 2013)

10. F.F. Bryukhan, A.Yu. Vinogradov, A.A. Lavrusevich, Meteorology and Hydrology, no. 11 (2017) 